\title{
Biotechnological improvement of ornamental plants ${ }^{(1)}$
}

\author{
FLAVIA SOLEDAD DARQUI(2), LAURA MABEL RADONIC(2), \\ HORACIO ESTEBAN HOPP(2),(3), MARISA LÓPEZ BILBAO(2)*
}

\begin{abstract}
The discovery of commercial transgenic varieties of orange petunias sold in Europe and the United States although they had never reached the approved status, and the consequent recommendation to destroy them, was the trigger to discuss about biotechnological improvement of ornamental plants. Inside the restricted world of 26 vegetal transgenic species, according to the ISAAA's reports (http://www.isaaa.org), there are three ornamental species: carnation, rose and the Beijing University developed petunia; all of them with the same trait, a change in their colour. On the other hand, in 2014, the whole-genome sequence of carnation appeared which was the first and until now the only one among ornamental species. In this context, we review the publications from the last five years in petunia, rose, chrysanthemum and carnation. In these papers there are detailed descriptions of modification of the cascade of genes and transcription factors involved in stress situations, in different developmental stages and their regulation through different plant hormones. This knowledge will allow breeding for better and new varieties with changes in their abiotic or biotic stress tolerance, altered growth or yield and modified product quality as colour or fragrance.
\end{abstract}

Keywords: GMO, petunia, rose, chrysanthemum and carnation.

\begin{abstract}
RESUMO
Melhoramento biotecnológico de plantas ornamentais

A descoberta de variedades transgênicas de petúnias laranja vendidas na Europa e nos Estados Unidos que nunca alcançaram o status aprovado e a consequente recomendação de destruí-las foi o fator desencadeador para a discussão sobre a melhoria biotecnológica de plantas ornamentais. Dentro do mundo estrito de 26 espécies transgênicas vegetais, de acordo com os relatórios do ISAAA (http://www.isaaa.org), existem três espécies ornamentais: cravo, rosa e as petúnias desenvolvidas pela Universidade de Pequim que tem como característica mudança na cor. Por outro lado, em 2014 foi realizado pela primeira vez o sequenciamento completo do genoma do cravo que é o único sequenciado entre as espécies ornamentais. Neste contexto, revisamos as publicações dos últimos cinco anos em petúnia, rosa, crisântemo e cravo. Nestes trabalhos, há descrições detalhadas da modificação da cascata de genes e fatores de transcrição envolvidos em situações de estresse, diferentes estágios do crescimento e sua regulação através de diferentes hormônios vegetais. Este conhecimento contribuirá diretamente no melhoramento vegetal, o qual permitirá o desenvolvimento de novas variedades que sejam resistentes a diferentes situações de estresse abiótico ou biótico, alterações nos fatores que contribuem para o crescimento ou produtividade e modificações nos parâmetros de qualidade (como cor ou fragrância).
\end{abstract}

Palavras-chave: OGM, petúnia, rosa, crisântemo, cravo.

\section{INTRODUCTION}

At the beginning of 2017 there was some news that surprized many people: some of the petunia commercial strains, in Europe and the United States (US), were transgenic. Dr. Teeri, a plant biologist, who had studied plant pigments at the University of Helsinki, noticed some vivid orange petunias in a planter of the train station in Helsinki. He remembered the engineering experiment done by Peter Meyer published in 1987 in Nature (MEYER et al., 1987), where petunias carried a maize gene that produce pelargonidin, a pigment that enabled them to adopt a salmon colour. Dr. Teeri took a sample, as he also knew that the genetically modified (GM) petunias never reached commercial status, and confirmed they were transgenic with a DNA insert matching the transgene described in the paper from 1987. After this analysis, he bought online other orange petunia seed varieties which were also carrying the same construction (BASHANDY and TEERI 2017). This discovery became known by a regulator at the Finnish Board for Gene Technology and on $27^{\text {th }}$ April this year the Finland's food safety body, called for eight petunia varieties to be removed from the market. A week later, an investigation made by the U.S. Department of Agriculture's (USDA) Animal and Plant Health Inspection Service (APHIS) revealed 10 varieties of genetically engineered (GE) petunia, and 21 others "implicated as potentially GE", and asked growers and sellers to incinerate, autoclave, bury, compost, or dispose plants from those varieties in a landfill. This interesting story, known now as the "transgenic

DOI: http://dx.doi.org/10.14295/oh.v23i3.1105

${ }^{(1)}$ Received in 10/07/2017 and accepted in 13/09/2017

${ }^{(2)}$ Instituto Nacional de Tecnología Agropecuaria (INTA), Instituto de Biotecnología, Buenos Aires-BA, Argentina.

(3)Universidad de Buenos Aires, Facultad de Ciencias Exactas y Naturales, Buenos Aires-BA, Argentina.

"Corresponding author: lopezbilbao.marisa@inta.gob.ar

Licensed by CC BY 4.0 
petunia carnage" (SERVICK, 2017) reveals several things about plant biotechnology, GMO (genetically modified organism) perception and regulation and the state of art in biotechnological improvement of ornamental plants.

Some people could think that all ornamental plants, or at least an important group of them, are transgenic, as ornamental plants may not need any regulation as they are just for pleasure, decoration and ornament, not to feed humanity. Nevertheless this is furthest away from reality.

The International Service for the Acquisition of Agribiotech Applications (ISAAA) features the Biotech/ GM crop events and traits that have been approved for commercialization, planting and/or for import for food and feed use worldwide (ISAAA GM Approval Database). The database shows that only three ornamental species can be found: petunia (Petunia hybrida), rose (Rosa hybrida) and carnation (Dianthus caryophyllus). In the case of petunia there is only one transgenic event developed by the Beijing University where the expression of the chalcone synthase $A$ gene resulted in flower colour alterations and in the cosuppression of transgenes and endogenous genes (LI et al., 2001). There are two transgenic rose events registered in the ISAAA database (http://www.isaaa.org), both carrying the $5 A T$ and $b p 40\left(f 3^{\prime} 5\right.$ ' $h$ ) genes from Torenia sp. and Viola wittrockiana, respectively, to modify the rose colour to blue http://www.suntory.com/sic/research/s bluerose/story/; KATSUMOTO et al., 2007). Finally, there are 19 events listed for carnation. All of them carry the $\operatorname{sur} B$ gene from Nicotiana tabacum, which confers tolerance to sulfonylurea herbicides and other acetolactate synthase (ALS) inhibiting herbicides and the $d f r$, hfl $\left(f 3^{\prime} 5^{\prime} h\right)$ and cytb5 Petunia hybrida genes to obtain different colours (FUKUI et al. 2003). The petunia genes were introduced, in pairs or all together, to generate purple or blue flowers. Besides, one of these events was also transformed with a modified transcript of the 1-amino-cyclopropane-1-carboxylic acid (ACC) synthase gene from Dianthus caryophyllus to reduce the synthesis of endogenous ethylene, delaying senescence and promoting longer vase life.

Both bluish carnations and roses can be found in the market, but with restrictions according to the fact that they are GMO and that several countries have banned their production and/or commercialization. Carnation flowers were the first GM flowers to be commercialized in the world. They are known as the Moonseries of Suntory (http://www.suntory.com/sic/), who declare that currently they are produced in Colombia and Ecuador, and sold primarily in US and in some European countries. Also, six varieties with different dark and light colour combinations are sold in Japan. In the case of the bluish rose, its development was announced in 2004 and the permission to commercially sell exclusively in Japan the "SUNTORY blue rose APPLAUSE" was obtained in 2008.

Regarding the transgenic petunias mentioned at the beginning, there are no official transgenic petunias released to the commercial circuit worldwide or another transgenic ornamental species.

This situation is not exclusive to the ornamental species; it is a common situation if we consider the huge number of scientific papers, magazines and books devoted to plant molecular research and biotechnological breeding versus the fact that there are only 26 transgenic species, according to the ISAAA's reports (http://www.isaaa. org). This restricted group of transgenic improved plants, besides carnation, rose and the petunia developed by the Beijing University, is integrated by crops (maize, wheat, rice), oilseeds (soybean, canola), fruits (papaya, plum, melon, apple), trees (eucalyptus, poplar), grasses (flax, creeping bentgrass, alfalfa), vegetables (eggplant, chicory, squash, sweet pepper, potato, tomato, bean, sugar beet) and industrial crops (cotton, tobacco). And the traits that were modified are only few, being the most common herbicide tolerance and insect resistance. Other traits include abiotic stress tolerance, altered growth or yield, disease resistance, pollination control systems and modified product quality.

Clearly, the difficulties and costs accompanying the deregulation process of a GMO hinder the obtaining of new varieties (AUER, 2008). In fact, deregulating a GMO takes even more time and costs than the research and development of a new event. This issue is deeply detailed for ornamental species in the review of Chandler and Sanchez, under the subtitle Hurdles to Commercialisation (CHANDLER and SANCHEZ 2012).

While a more adequate approximation arrives to the regulatory stage of new developments, the episode of the transgenic petunia mentioned at the beginning could be used to learn that transgenic and non-transgenic petunias coexisted, they arrived to the market and were sold because the public chose them and several companies and growers could produce them without losing or contaminating their other non-transgenic varieties. In short, that transgenic petunias did not overrun the ground or affect plant biodiversity because of the dispersal of transgenic pollen.

In spite of the above explanations, it must also be taken into consideration that the advances in ornamental species are rather slower than in other economical important plants. In 2013 it was published the list of the fifty-five plant genomes that have been sequenced until that moment which included 49 different species and not one was ornamental (MICHAEL and JACKSON, 2013). Just, in 2014, the whole-genome sequence of carnation (Dianthus caryophyllus L.) cv. 'Francesco' was published (YAGI et al., 2014). This progress was possible because carnation has a comparatively small nuclear genome, approximately four times the size of the Arabidopsis thaliana nuclear genome. Besides, most carnation cultivars are diploid. The estimated genome size of carnation $(670 \mathrm{Mb})$ is the smallest compared with other ornamental flowers (Rosa hybrida (1.1 Gb), Antirrhinum majus (1.5 Gb), Petunia hybrid (1.6 Gb), Chrysanthemum morifolium $(9.4 \mathrm{~Gb})$ and Tulipa gesneriana $(26 \mathrm{~Gb})$ ), according to the Plant $\mathrm{C}$-values database (http://data.kew.org/cvalues/).

Nevertheless, there is an important amount of research and development carried out in some ornamental species, that goes beyond transgenesis and include NBTs and genomic studies, especially in petunia, for its importance as model system, and in rose, chrysanthemum and carnation for their economic importance and their background in 
research. These advances could allow, in a near future, to produce novel varieties to be incorporated to the market and sold in several countries. These researches can be summarized by trait which can be grouped in plant pigments and flower colour, induction of early flowering, floral anatomy and morphology, fragrance engineering, abiotic and biotic stress tolerance and shelf life enhancement. An excellent review about these subjects was published this year collecting detailed information about research in flower transgenesis during the first decade of this century (NOMAN et al., 2017).

In the following lines we review the publications from the last five years in these four species that show a very promising future.

\section{PETUNIA}

As well as being one of the most popular bedding flowers worldwide, Petunia hybrida has a long history as a model in plant molecular biology and genetics, given its several lab-model characteristics such as a short lifecycle, easy culture conditions, easy propagation (both sexual and asexual), biochemical analysis and the development of stable and transient transformation protocols, including the studies that produced the orange petunia found in Helsinki train station. According to this history, there is an event developed by the Beijing University with an altered flower colour integrating the short list of ornamental transgenic events (ISAAA GM Approval Database). It is expected that advances in sequencing technologies will expand studies in this plant (VANDENBUSSCHE et al., 2016).

Thus, petunia is a very attractive model to study a large number of subjects, and genetic transformation is widely used as an approach for functional genomics. Moreover, it is one of the first ornamental plants in which the CRISPRCas9 technology was evaluated (SUBBURAJ et al., 2016; ZHANG et al., 2016).

Considering the last five years, scientific literature include transgenic petunia events obtained to study floral pigmentation (BOASE et al., 2015; CHU et al., 2015; AI et al., 2016; SHAIPULAH et al., 2015), biotic (WANG et al., 2013a; GARGUL et al., 2015; SUN et al., 2016) and abiotic stress (ESTRADA-MELO et al., 2015), selfincompatibility (LI et al., 2014; KUBO et al., 2016), adventitious root formation (LISCHWESKI et al., 2015), floral development (MOREL et al., 2017; O'DONOGHUE et al., 2017; YUE et al., 2017), plant architecture (LIANG et al., 2014; GARGUL et al., 2015), flower senescence (WANG et al., 2013a; WANG et al., 2013b; YIN et al., 2015), floral volatiles (CNA'ANI et al., 2015; SHAIPULAH et al., 2015; ADEBESIN et al., 2017; OLIVA et al., 2017), herbivore defence (KESSLER et al., 2013; SASSE et al., 2016), and others.

From the perspective of petunia as ornamental plant, floral pigmentation, plant architecture and flower senescence are among the most relevant features.

Regarding floral pigmentation Boase et al. (2015) investigated if $M d-M Y B 10_{R \sigma}$, an allelic variant of the anthocyanin regulator in apple, is capable to generate petunia plants with novel pigmentation patterns. Stable transgenic petunias containing the $M d-M Y B 10_{R 6}$ gene lacked foliar pigmentation but had coloured flowers, complementing the an 2 phenotype of 'Mitchell' petunia. The absence of foliar pigmentation was due to the failure of the Md-MYB10R6 gene to self-activate in vegetative tissues, because additional protein partners are required for Md-MYB10 to activate target genes in this heterologous system.

In the work of Chu et al. (2015), petunia was transformed with the Dihydroflavonol 4-reductase (DFR) genes from Rosa chinensis and Calibrachoa hybrida to study the effect on DFR expression and enzyme activity. Exogenous DFR genes were expressed in all tissues at different levels. Both of them exhibited a high expression level in petals starting to open and anthocyanin concentrations changed according to DFR enzyme activity.

In 2016, Ai et al. reported that the sucrose-induced anthocyanin accumulation in vegetative tissue of petunia plants requires anthocyanin regulatory transcription factors (TF). This was discovered by observing the effects of different sucrose concentrations on plant growth and anthocyanin accumulation in transgenic petunia carrying the anthocyanin regulatory TFs genes $B$-Peru $+m P A P 1$ or $R S M Y B 1$. Anthocyanin accumulation was not observed in wild type plants in any treatments, whereas a range of anthocyanin accumulation was observed in transgenic plants.

As to plant architecture, Liang et al. (2014) isolated three putative GID1 genes, encoding GA (gibberellic acid) receptors, from petunia (PhGID1A, PhGIDIB and $P h G I D 1 C$ ). VIGS (Virus-induced Gene Silencing) of these genes results in growth inhibition, dark-green leaves and late-flowering and transgenic plants overexpressing the gai mutant (gai-1) gene from Arabidopsis under an inducible promoter, showed growth delay and short internodes.

Also in this respect, Gargul et al. (2015) evaluated the effect of overexpressing the MAP kinase 4 nuclear substrate 1 (MKS1) gene from Arabidopsis in petunia. Transgenic plants showed a dwarfed phenotype, with shorter stems and internodes, delayed flowering and increased tolerance to Pseudomonas syringae pv. tomato.

Regarding floral senescence, it is known that the inducible expression of the mutant ethylene receptor etr1-1 from Arabidopsis causes ethylene insensitivity in petunia. Wang et al. (2013a) generated transgenic petunia plants overexpressing the etr $1-1$ gene under the control of an inducible promoter, and inoculated them with Botrytis cinerea. The induced expression of etr 1-1 resulted in retarded senescence but also in reduced disease symptoms. Transgenic plants grew normally without the inducer but when the promoter was induced, transcription of etr1-1 in flowers increased, transgenic flowers doubled lifetime and the peak of ethylene production was delayed. Also transcripts of many putative genes encoding TFs were down-regulated by etr $1-1$ induced expression at the early stage. Besides, putative genes involved in GAs biosynthesis, response to jasmonic acid/GAs stimulus, cell wall modification, ethylene biosynthesis, and cell death 
were down-regulated associating with etr1-1 induced expression (WANG et al., 2013b).

Yin et al. (2015) found that the basic helix-loop-helix (bHLH) TF PhFBH4 regulates flower senescence by modulating the ethylene biosynthesis pathway in petunia. VIGS of PhFBH4 extended flower longevity, while transgenic petunia flowers overexpressing $\mathrm{PhFBH} 4$ showed a reduction in flower lifetime. Also, abundance of transcripts of senescence-related genes changed in transgenic flowers. Furthermore, silencing or overexpression of $\mathrm{PhFBH} 4$ reduced or increased, respectively, transcript abundances of important ethylene biosynthesis-related genes, influencing ethylene production.

\section{CHRYSANTHEMUM}

There were several reports on transgenic plants with different traits, including those related to improve the Agrobacterium transformation protocol, like the search for alternatives to the use of antibiotic resistance genes as selective marker. The pmi gene that encodes phosphomannose-isomerase, an enzyme that allows transformed cells to utilize mannose as the only carbon source, and Roseal gene from Antirrhinum majus that regulates the anthocyanin biosynthesis and could be used as a visual selection marker as red coloured stems can be scored after transformation.

In relation to abiotic stress resistance, it was published that the constitutive expression of CCSOS1 and CdICE1 genes, both from different Chrysanthemum species, (CcSOS1 encodes a plasma membrane $\mathrm{Na}^{+} / \mathrm{H}^{+}$antiporter involved in the long distance transport and exudation of $\mathrm{Na}^{+}$ions and CdICEl encodes a MYC-like bHLH transcriptional activator) enhances the abiotic stress tolerance of chrysanthemum variety 'Jinba' with respect to their sensitivity to low temperature, drought and salinity, as measured by visible damage and plant survival (SONG et al., 2014a). Similarly, the overexpression of the chrysanthemum CgHSP70 gene (belonging to the HSP70 family) produces plants with an increased peroxidase activity, higher proline content and inhibited malondialdehyde content, allowing these transgenic lines to recover better after heat stress, drought or salinity, demonstrating the positive effect of this heat shock protein (SONG et al., 2014b).

Proceeding with abiotic stress, transgenic plants overexpressing the TF DgNAC1, obtained also from chrysanthemum, demonstrated it works as a positive regulator in responses to salt stress (WANG et al., 2017). These transgenic plants were more resistant to salt, showed a higher survival rate, lower electrolyte conductivity, fewer accumulation of malondialdehyde and reactive oxygen species $\left(\mathrm{H}_{2} \mathrm{O}_{2}\right.$ and $\left.\mathrm{O}_{2}^{-}\right)$, greater activities of superoxide dismutase, peroxidase and catalase, as well as more proline content than non-transgenic plants under salt stress. Furthermore, under this stress condition, transgenic chrysanthemum stress-responsive genes were greater upregulated than in non-transgenic plants, showing that this TF may be essential for molecular breeding of salt-tolerant plants.
AnotherTF,CmWRKY17 isolated from Chrysanthemum morifolium and belonging to the group II WRKY family, is induced by salinity in chrysanthemum (LI et al., 2015). Its overexpression in transgenic chrysanthemum and Arabidopsis increased the sensitivity to salinity stress and reduced the expression of several stress-related genes (AtRD29, AtDREB2B, AtSOS1, AtSOS2 and AtSOS3) suggesting that CmWRKY17 may increase the salinity sensitivity in plants as a transcriptional repressor. These plants have no commercial interest but allow a functional genomic approach to know that this TF proper regulation could lead to plants resistant to salinity.

In relation to biotic stress publications, there is an interesting report where transgenic chrysanthemums were obtained by introducing a modified cry $1 \mathrm{Ab}$ gene of Bacillus thuringiensis var. kurstaki HD-1 (mcbt) and a modified sarcotoxin IA gene of Sarcophaga peregrine (msar) (SHINOYAMA et al., 2015). The GM chrysanthemums accumulated more than $1.31 \mu \mathrm{g}$ of Cry $1 \mathrm{Ab}$ per mg of total soluble protein and showed a strong resistance against 4 species of lepidopteran larvae (Helicoverpa armigera and others) that died during the first instar stage. Also a strong resistance against white rust (Puccinia horiana) was observed, with more than $19.5 \mu \mathrm{g}$ per $\mathrm{g}$ of sarcotoxin IA peptide of fresh weight of leaves.

A change in flower colour is an important objective, Brugliera et al. (2013) published that production of anthocyanins derived from delphinidin in chrysanthemum petals led to a novel bluish flower colour. This change was done together with optimization of transgene expression and selection of the host cultivars with the $F 3^{\prime} 5^{\prime} H$ pansy gene under the control of a chalcone synthase promoter fragment from rose.

Another important characteristic in ornamental plants is flower and plant shape and a possible strategy is to modify the shape by genetic manipulation of regulators of floral organ such as MADS-box TFs which play key roles in this process. Although this research area is not so advanced, the ectopic effect of a candidate $\mathrm{TF}$ gene is a reliable approach. The Chrysanthemum flower shape was analysed after ectopic expression of HAM59, an AGAMOUS-like cDNA from Helianthus (SHULGA et al., 2015). Stamens were transformed into petal-like structures, resembling the double flower phenotype in Arabidopsis agamous mutants, ray floret petals were shorter than control and ligule tips were divided. However, there were no homeotic changes of floral organs in ray florets, concluding that ectopic expression of sunflower HAM59 gene modified androecium to corolla-like tissues and leads to male-sterility.

There are several papers on more basic research as the discovery of new genes, TF, miRNA, and their putative activity and regulation which may result of interest for future developments.

In spite of the above mentioned papers in genetic transformation and the usage of homologous genes and sequences, it must be taken into consideration that Chrysanthemum morifolium is a hexaploid with a large genome and, as mentioned previously, lacks whole-genome information. These difficulties were not an impediment 
to the employment of gene editing technologies, using the CRISPR/Cas9 system to introduce mutations. For this proof of concept, transgenic chrysanthemum plants expressing the yellowish-green fluorescent protein gene from Chiridius poppei (CpYGFP) were constructed and targeted for gene editing (KISHI-KABOSHI et al., 2017). The DNA sequencing analysis and fluorescence observations indicated that cells containing the mutated CpYGFP gene grew independently of cells containing the original $C p Y G F P$ gene in one callus, and it was obtained a CRISPR CpYGFP shoot containing a mutation in the CpYGFP sequence. This is the first report of gene editing in chrysanthemum and one of the first in horticultural species, which could be very promising to avoid regulation issues, at least in some cases.

\section{ROSE}

Besides the characteristics shared with the other important ornamental commodities, as high commercial value and widespread cultivation, Roses possess valuable secondary metabolites which are used in the cosmetic and perfume industry. In spite of this importance, there are not extensive reports of transgenic rose plants, besides the famous transgenic "blue" roses reported in 2004 (KATSUMOTO et al., 2007). The transgenic events obtained include resistance to black spot (MARCHANT et al., 1998; KAUFMANN et al., 2003), resistance to powdery mildew (LI et al., 2003), production of scent compounds (ZVI et al., 2012), improved vase life (DERKS et al., 1995), and improved rooting characteristics (VAN DER SALM et al., 1997). Among the most recent reports in which transformation techniques were used in rose, it can be found mostly transient VIGS-silenced plants in which genes involved in processes such as response to water deficit, petal development or senescence were evaluated.

Rose petal growth depends upon cell expansion at later stages of flower opening which is inhibited by ethylene on abaxial subepidermis cells (MA et al., 2008). The TF RhNAC100 was induced by ethylene and its silencing increased petal size and promoted cell expansion in the petal abaxial subepidermis (PEI et al., 2013). The silencing of another TF, RhAG (a homolog of the A. thaliana AGAMOUS C-function gene) increased petal number while low temperatures restricts it spatial expression area by increasing the methylation level of the $R h A G$ promoter (MA et al., 2015). Liu et al. (2013) found an organ-specific role for ethylene in rose petal expansion, as during dehydration there was an increase in ethylene production in sepals while in rehydration ethylene levels increased in sepals and gynoecia, increasing in both tissues the expression of the ethylene synthesis RhACS1 and $R h A C S 2$ genes, that were evaluated also using the strategy of gene silencing. More recently, another gene involved in rehydration-triggered ethylene production in rose gynoecia has been reported (CHEN et al., 2017). The temporal and spatial-specific ethylene production in rose gynoecia was previously attributed to a transient activation of the MAP KINASE KINASE RhMPK6-RhACS1 cascade. It was found that between $R h M K K 2 / 4 / 5 / 9$ only $R h M K K 9$ showed a rapid and strong expression induced by rehydration. Silencing of $R h M K K 9$ decreased rehydration-triggered ethylene production and the expression of several ethyleneresponsive genes in the petals.

Another aspect of interest in rose breeding is delayed senescence in flowers. Several phytohormones are implied in the regulation of the senescence process. Abscisic acid (ABA) and ethylene promote petal senescence while gibberellins (GAs) and cytokines (CTKs) are antagonists of ABA and ethylene in this process. In 2013 Zakizadeh et al. reported the transformation of miniature potted rose with the cytokine biosynthesis ipt (isopentenyl transferase) gene from A. tumefaciens, under the SAG12 promoter (which regulates the expression of a highly senescencespecific gene from Arabidopsis), this same gene construct had already been successfully transferred to other plants, as Petunia (CHANG et al., 2003; CLARK et al., 2004). Transgenic plants showed delay leaf senescence and enhanced resistance to exogenous ethylene, due to specific up-regulation of the ipt gene under senescence promoting conditions. Also in petal senescence, it was found that the TF RhHB1 was strongly expressed in senescing petals and mediates the antagonistic effect of GAs on ABA and ethylene (LÜ et al., 2014). RhHBI silencing delayed the ABA- or ethylene-mediated senescence and blocked the ABA- or ethylene-induced reduction in expression of the $\mathrm{GA}_{20}$ oxidase encoded by RhGA20ox1. Furthermore, RhHB1 directly binds to the RhGA20ox 1 promoter and the silencing of $R h G A 20 \mathrm{ox} 1$ gene promoted petal senescence. These results suggest that RhHB1 mediates the antagonistic effect of GAs on ABA and ethylene during rose petal senescence, and that the promotion of petal senescence by ABA or ethylene operates through an RhHB1-RhGA20ox1 regulatory checkpoint. Similarly, and more recently, Wu et al. (2017) found an ethylene-induced RhHB6-RhPR10.1 regulatory module that functions as a brake of ethylene promoted senescence through increasing the CTK content in rose. Silencing of $R h P R 10.1$, a pathogenesis-related PR-10 family gene from rose and highly expressed in different floral organs during senescence, accelerated flower senescence accompanied by a reduction in CTK content and in the expression of three CTK signalling pathway genes. The enhanced rate of petal senescence in RhPR10.1-silenced plants was restored to normal levels by CTK treatment. Finally, the TF RhHB6 was observed to bind to the RhPR10.1 promoter, and silencing of its expression also promoted flower senescence. So, the effect of RhHB6 and RhPR10.1 silencing is that both accelerate flower senescence. The conclusion is that the ethylene-induced RhHB6-RhPR 10.1 regulatory module inhibits ethylene-induced flower senescence through increasing the levels of CTKs.

\section{CARNATION}

Carnation has the privilege of being the only ornamental species with its complete genome sequenced and published, as well as integrating the trio of transgenic ornamental species that are commercialized in the world, with 19 
events of bluish flowers. However, in this case, the number of works in biotechnological improvement and molecular biology is lower than in the other three species analysed in this review, possibly due to the high number of publications made in the previous decade, between 2002 and 2012.

Among the latest publications we can highlight the study of ethylene biosynthetic genes and senescence-related genes were studies in the flowers of 532-6 line, an ultralong flower life, in comparison with 'Francesco' a control cultivar and 'Miracle Rouge' (MR), another cultivar with long flower life (TANASE et al., 2015). The study of genes DcACS1 and DcACO1 (ethylene biosynthesis), DcbGal, DcGST1 and DcLip (senescence-related), DcCP1 and DcCPIn (a cysteine proteinase and its inhibitor) suggests that the extended flower life of MR and 532-6 depends on reduced levels of ethylene production, low levels of ethylene biosynthetic gene expression, and senescencerelated gene expression.

A basic approach was also done to identify genes involved in heat shock stress as standard carnation varieties perform well under cool climates but are very susceptible to high temperatures. The transcriptome analysis was performed to generate expression profiles of heat stress (HS)-responsive genes, after sequencing a cDNA library constructed with mixed RNA from carnation leaves subjected to $42{ }^{\circ} \mathrm{C}$ HS and $46{ }^{\circ} \mathrm{C}$ HS (WAN et al., 2015). Overall, 11,471 genes were identified which showed a significant response to one or more HS treatment times. In addition, based on GO and metabolic pathway enrichment analyses, a series of candidate genes involved in thermotolerance responses were selected and characterized.

\section{CONCLUSIONS}

Detailed knowledge of the cascade of genes and $\mathrm{TF}$ involved in stress situations as well as in different development stages and their regulation through different plant hormones will allow to modify them, increasing, reducing or repressing their expression. These modifications will happen by transgenesis, by applying techniques of genetic editing or combining both strategies. No doubt, these tools will lead to new varieties of these species by the direct use of these technologies or by applying traditional crosses using varieties studied in depth. In addition, the orange petunias incident showed that they are harmless. Humanity will continue breeding and looking for better and new varieties, now with the help of these tools developed since the 90s with the emergence of genetic engineering. The future is promising.

\section{ACKNOWLEDGMENTS}

We are grateful to $\mathrm{PhD}$ Wanderson Marques da Silva for translating the abstract to Portuguese. This manuscript was funded by INTA Projects: PNHFA1106073, PNBIO1131023 and 1131024.

\section{AUTHORS CONTRIBUTIONS}

FSD, LMR, HEH and MLB have contributed equally to this manuscript, including writing and discussion.

\section{REFERENCES}

ADEBESIN, F.; WIDHALM, J.R.; BOACHON, B.; LEFÈVRE, F.; PIERMAN, B.; LYNCH, J.H.; ALAM, I.; JUNQUEIRA, B.; BENKE, R.; RAY, S.; PORTER, J.A.; YANAGISAWA, M.; WETZSTEIN, H.Y.; MORGAN, J.A.; BOUTRY, M.; SCHUURINK, R.C.; DUDAREVA, N. Emission of volatile organic compounds from petunia flowers is facilitated by an ABC transporter. Science, v.356, n.6345, p.1386-1388, 2017. DOI: <10.1126/science. aan0826>

AI, T.N.; NAING, A.H.; ARUN, M.; LIM, S.H.; KIM, C.K. Sucrose-induced anthocyanin accumulation in vegetative tissue of Petunia plants requires anthocyanin regulatory transcription factors. Plant Science, v.252, p.144-150, 2016. DOI: <10.1016/j.plantsci.2016.06.021>

AUER, C. Ecological risk assessment and regulation for genetically-modified ornamental plants. Critical Reviews in Plant Sciences, v.27, n.4, p.255-271, 2008. DOI: $<10.1080 / 07352680802237162>$

BASHANDY, H.; TEERI, T.H. Genetically engineered orange petunias on the market. Planta, v. 246, n.2, p 277 280, 2017. DOI: <10.1007/s00425-017-2722-8>

BOASE, M.R.; BRENDOLISE, C.; WANG, L.; NGO, H.; ESPLEY, R.V.; HELLENS, R.P.; SCHWINN, K.E.; DAVIES, K.M.; ALBERT, N.W. Failure to launch: the self-regulating $M d-M Y B 10_{R 6}$ gene from apple is active in flowers but not leaves of Petunia. Plant Cell Reports, v.34, n.10, p.1817-1823, 2015. DOI: <10.1007/s00299015-1827-4>

BRUGLIERA, F.; TAO, G.Q.; TEMS, U.; KALC, G.; MOURADOVA, E.; PRICE, K.; STEVENSON, K.; NAKAMURA, N.; STACEY, I.; KATSUMOTO, Y.; TANAKA, Y.; MASON, J.G. Violet/blue Chrysanthemums - metabolic engineering of the anthocyanin biosynthetic pathway results in novel petal colors. Plant and Cell Physiology, v.54, n.10, p.1696-1710, 2013. DOI: <10.1093/ $\mathrm{pcp} / \mathrm{pct} 110>$

CHANDLER, S.F.; SANCHEZ, C. Genetic modification; the development of transgenic ornamental plant varieties. Plant Biotechnology Journal, v.10, n.8, p.891-903, 2012. DOI: $<10.1111 /$ j.1467-7652.2012.00693.x> 
CHANG, H.; JONES, M.L.; BANOWETZ, G.M.; CLARK, D.G. Overproduction of cytokinins in petunia flowers transformed with $\mathrm{P}_{\mathrm{SAG} 12}$-IPT delays corolla senescence and decreases sensitivity to ethylene. Plant Physiology, v.132, n.4, p.2174-2183, 2003. DOI: <10.1104/pp.103.023945>

CHEN, J.; ZHANG, Q.; WANG, Q.; FENG, M.; LI, Y.; MENG, Y.; ZHANG, Y.; LIU, G.; MA, Z.; WU, H.; GAO, J.; MA, N. RhMKK9, a rose MAP KINASE KINASE gene, is involved in rehydration-triggered ethylene production in rose gynoecia. BMC Plant Biology, v.17, n.1, p.51, 2017. DOI: <10.1186/s12870-017-0999-1>

CHU, Y.X.; CHEN, H.R.; WU, A.Z.; CAI, R.; PAN, J.S. Expression analysis of dihydroflavonol 4-reductase genes in Petunia hybrida. Genetics and Molecular Research, v.14, n.2, p.5010-5021, 2015. DOI: <10.4238/2015. May.12.4>

CLARK, D.G.; DERVINIS, C.; BARRETT, J.E.; KLEE, H.; JONES, M. Drought-induced leaf senescence and horticultural performance of transgenic PSAG12ipt petunias. Journal of the American Society for Horticultural Science, v. 129, n. 1, p. 93-99, 2004

CNA'ANI, A.; MÜHLEMANN, J.K.; RAVID, J.; MASCI, T.; KLEMPIEN, A.; NGUYEN, T.T.H.; DUDAREVA, N.; PICHERSKY, E.; VAINSTEIN, A. Petunia $\times$ hybrida floral scent production is negatively affected by high $\square$ temperature growth conditions. Plant, Cell \& Environment, v.38, n.7, p.1333-1346, 2015. DOI: <10.1111/pce.12486>

DERKS, F.H.M.; VAN DIJK, A.J.; HÄNISCH TEN CATE, C.H.; FLORACK, D.E.A.; DUBOIS, L.A.M.; DE VRIES, D.P. Prolongation of vase life of cut roses via introduction of genes coding for antibacterial activity. Somatic embryogenesis and Agrobacterium-mediated transformation. Acta Horticulturae, v.405, p.205-209, 1995. DOI: <10.17660/ActaHortic. 1995.405.26>

ESTRADA-MELO, A.C.; MA, C.; REID, M.S.; JIANG, C.Z. Overexpression of an ABA biosynthesis gene using a stress-inducible promoter enhances drought resistance in petunia. Horticulture Research, v.2, p.15013, 2015. DOI: $<10.1038$ /hortres.2015.13>

FUKUI, Y.; TANAKA, Y.; KUSUMI, T.; IWASHITA, T.; NOMOTO, K. A rationale for the shift in colour towards blue in transgenic carnation flowers expressing the flavonoid 3',5'-hydroxylase gene. Phytochemistry, v.63, n.1, p.1523, 2003. DOI: < 10.1016/S0031-9422(02)00684-2>
GARGUL, J.M.; MIBUS, H.; SEREK, M. Manipulation of MKS1 gene expression affects Kalanchoë blossfeldiana and Petunia hybrida phenotypes. Plant Biotechnology Journal, v.13, n.1, p.51-61, 2015. DOI: <10.1111/ pbi.12234>

KATSUMOTO, Y.; FUKUCHI-MIZUTANI, M.; FUKUI, Y.; BRUGLIERA, F.; HOLTON, T.A.; KARAN, M.; NAKAMURA, N.; YONEKURA-SAKAKIBARA, K.; TOGAMI, T.; TAO, A.P.Q.G.; NEHRA, N.S.; LU, C.Y. DYSON, B.K.; TSUDA, S.; ASHIKARI, T.; KUSUMI, T.; MASON, J.G.; TANAKA, Y. Engineering of the rose flavonoid biosynthetic pathway successfully generated blue-hued flowers accumulating delphinidin. Plant and Cell Physiology, v.48, n.11, p.1589-1600, 2007. DOI: $<10.1093 / \mathrm{pcp} / \mathrm{pcm} 131>$

KAUFMANN, H.; MATTIESCH, L.; LÖRZ, H.; DEBENER, T. Construction of a BAC library of Rosa rugosa Thunb. and assembly of a contig spanning Rdrl, a gene that confers resistance to blackspot. Molecular Genetics and Genomics, v.268, n.5, p.666-674, 2003. DOI: $<10.1007 / \mathrm{s} 00438-002-0784-0>$

KESSLER, D.; DIEZEL， C.; CLARK, D.G.; COLQUHOUN, T.A.; BALDWIN, I.T. Petunia flowers solve the defence/apparency dilemma of pollinator attraction by deploying complex floral blends. Ecology Letters, v.16, n.3, p.299-306, 2013. DOI: <10.1111/ ele. $12038>$

KISHI-KABOSHI, M.; AIDA, R.; SASAKI, K. Generation of gene-edited Chrysanthemum morifolium using multicopy transgenes as targets and markers. Plant and Cell Physiology, v.58, n.2, p.216-226, 2017. DOI: $<10.1093 / \mathrm{pcp} / \mathrm{pcw} 222>$

KUBO, K.I.; TSUKAHARA, M.; FUJI, S.; MURASE, K.; WADA, Y.; ENTANI, T.; IWANO, M.; TAKAYAMA, S. Cullin1-P is an essential component of non-self recognition system in self-incompatibility in Petunia. Plant and Cell Physiology, v.57, n.11, p.2403-2416, 2016. DOI: <10.1093/ $\mathrm{pcp} / \mathrm{pcw} 152>$

LI, P.; SONG, A.; GAO, C.; WANG, L.; WANG, Y.; SUN, J.; JIANG, J.; CHEN, F.; CHEN, S. Chrysanthemum WRKY gene $C m W R K Y 17$ negatively regulates salt stress tolerance in transgenic chrysanthemum and Arabidopsis plants. Plant Cell Reports, v.34, n.8, p.1365-1378, 2015. DOI: $<10.1007 /$ s00299-015-1793-X> 
LI, S.; SUN, P.; WILLIAMS, J.S.; KAO, T.H. Identification of the self-incompatibility locus F-box protein-containing complex in Petunia inflata. Plant Reproduction, v.27, n.1, p.31-45, 2014. DOI: $<10.1007 /$ s00497-013-0238-3>

LI, X.; GASIC, K.; CAMMUE, B.; BROEKAERT, W.; KORBAN, S.S. Transgenic rose lines harboring an antimicrobial protein gene, Ace-AMPl, demonstrate enhanced resistance to powdery mildew (Sphaerotheca pannosa). Planta, v.218, n.2, p.226-232, 2003. DOI: $<10.1007 / \mathrm{s} 00425-003-1093-5>$

LI, Y.; XI, Y.; ZHANG, Z.; HUANG, X.; LI, Y. Cosuppression in transgenic Petunia hybrida expressing chalcone synthase A ( chsA). Science in China Series C: Life Sciences, v.44, n.6, p.661-668, 2001. DOI: $<10.1007 /$ BF02879361>

LIANG, Y.C., REID, M.S.; JIANG, C.Z. Controlling plant architecture by manipulation of gibberellic acid signalling in petunia. Horticulture Research, v.1, p.14061, 2014. DOI: $<10.1038$ /hortres.2014.61>

LISCHWESKI, S.; MUCHOW, A.; GUTHÖRL, D.; HAUSE, B. Jasmonates act positively in adventitious root formation in petunia cuttings. BMC plant biology, v.15, n.1 p.229, 2015. DOI: $<10.1186 / \mathrm{s} 12870-015-0615-1>$

LIU, D.; LIU, X.; MENG, Y.; SUN, C.; TANG, H.; JIANG, Y.; KHAN, M.A.; XUE, J.; MA, N.; GAO, J. An organspecific role for ethylene in rose petal expansion during dehydration and rehydration. Journal of Experimental Botany, v.64, n.8, p.2333-2344, 2013. DOI: $<10.1093 / \mathrm{jxb} /$ ert092>

LÜ, P., ZHANG, C., LIU, J., LIU, X., JIANG, G., JIANG, X., KHAN, M.A.; WANG, L.; HONG, B.; GAO, J. RhHB1 mediates the antagonism of gibberellins to $\mathrm{ABA}$ and ethylene during rose (Rosa hybrida) petal senescence. The Plant Journal, v.78, n.4, p.578-590, 2014. DOI: $<10.1111 /$ tpj.12494>

MA, N., XUE, J., LI, Y., LIU, X., DAI, F., JIA, W., LUO, Y.; GAO, J. Rh-PIP2; 1, a rose aquaporin gene, is involved in ethylene-regulated petal expansion. Plant Physiology, v.148, n.2, p.894-907, 2008. DOI: <10.1104/ pp.108.120154>

MA, N.; CHEN, W.; FAN, T.; TIAN, Y.; ZHANG, S.; ZENG, D.; LI, Y. Low temperature-induced DNA hypermethylation attenuates expression of $R h A G$, an AGAMOUS homolog, and increases petal number in rose (Rosa hybrida). BMC Plant Biology, v.15, n.1, p.237, 2015. DOI: $<10.1186 / \mathrm{s} 12870-015-0623-1>$
MARCHANT, R.; DAVEY, M.R.; LUCAS, J.A.; LAMB, C.J.; DIXON, R.A.; POWER, J.B. Expression of a chitinase transgene in rose (Rosa hybrida L.) reduces development of blackspot disease (Diplocarpon rosae Wolf). Molecular Breeding, v.4, n.3, p.187-194, 1998. DOI: $<10.1023 / \mathrm{A}: 1009642707505>$

MEYER, P.; HEIDMANN, I.; FORKMANN, G.; SAEDLER, H. A new petunia flower colour generated by transformation of a mutant with a maize gene. Nature, v.330, n.6149, p.677-678, 1987. DOI: $<10.1038 / 330677 a 0>$

MICHAEL, T.P.; JACKSON, S. The first 50 plant genomes. The Plant Genome, v.6, n.2, 2013. DOI: <10.3835/ plantgenome2013.03.0001in>

MOREL, P.; HEIJMANS, K.; ROZIER, F.; ZETHOF, J.; CHAMOT, S.; RODRIGUES BENTO, S.; VIALETTEGUIRAUD, A.; CHAMBRIER, P.; TREHIN, C.; VANDENBUSSCHE, M. Divergence of the Floral A-Function between an Asterid and a Rosid Species. The Plant Cell Online, v.28, n.8, p.tpc.00098.2017, 2017. DOI: $<10.1105 /$ tpc. $17.00098>$

NOMAN, A.; AGEEL, M.; DENG, J.; KHALID, N.; SANAULLAH, T.; SHUILIN, H. Biotechnological advancements for improving floral attributes in ornamental plants. Frontiers in Plant Science, v.8, p.530, 2017. DOI: $<10.3389 /$ fpls.2017.00530>

O'DONOGHUE, E.M.; SOMERFIELD, S.D.; DEROLES, S.C.; SUTHERLAND, P.W.; HALLETT, I.C.; ERRIDGE, Z.A.; BRUMMELL, D.; HUNTER, D.A. Simultaneous knock-down of six $\beta$-galactosidase genes in petunia petals prevents loss of pectic galactan but decreases petal strength. Plant Physiology and Biochemistry, v.113, p.208-221, 2017. DOI: $<10.1016 /$ j.plaphy.2017.02.005>

OLIVA, M.; BAR, E.; OVADIA, R.; PERL,A.; GALILI, G.; LEWINSOHN, E.; OREN-SHAMIR, M. Phenylpyruvate contributes to the synthesis of fragrant benzenoidphenylpropanoids in Petunia $\times$ hybrida flowers. Frontiers in Plant Science, v.8, p.769, 2017. DOI: $<10.3389 /$ fpls.2017.00769>

PEI, H.; MA, N.; TIAN, J.; LUO, J.; CHEN, J.; LI, J.; ZHENG, Y.; CHEN, X.; FEI, Z.; GAO, J. An NAC transcription factor controls ethylene-regulated cell expansion in flower petals. Plant Physiology, v.163, n.2, p.775-791, 2013. DOI: <10.1104/pp.113.223388>

SASSE, J.; SCHLEGEL, M.; BORGHI, L.; ULLRICH, F.; LEE, M.; LIU, G.W.; GINER, J.L.; KAYSER, O.; BIGLER, L.; MARTINOIA, E.; KRETZSCHMAR, T. Petunia hybrida PDR2 is involved in herbivore defense by controlling steroidal contents in trichomes. Plant, Cell \& Environment, v.39, n.12, p.2725-2739, 2016. DOI: $<10.1111 /$ pce.12828> 
SERVICK, K. The strange case of the orange petunias. Science, v.356, n.6340, p.79226, 2017. DOI: $<10.1126 /$ science.356.6340.792>

SHAIPULAH, N.F.M.; MUHLEMANN, J.K.; WOODWORTH, B.D.; VAN MOERKERCKE, A.; VERDONK, J.C.; RAMIREZ, A.M.; HARING, M.A.; DUDAREVA, N.; SCHUURINK, R. CCOAOMT downregulation activates anthocyanin biosynthesis in petunia. Plant Physiology, v.175, n.1 p.01646.2015, 2015. DOI: <10.1104/pp.15.01646>

SHINOYAMA, H.; MITSUHARA, I.; ICHIKAWA, H.; KATO, K.; MOCHIZUKI, A. Transgenic chrysanthemums (Chrysanthemum morifolium Ramat.) carrying both insect and disease resistance. Acta Horticulturae, v.1087, p.485497, 2015. DOI: <10.17660/ActaHortic.2015.1087.66>

SHULGA, O.A.; MITIOUCHKINA, T.Y; SHCHENNIKOVA, A.V.; SKRYABIN, K.G.; DOLGOV, S.V.. Chrysanthemum modification via ectopic expression of sunflower MADS-box gene HAM59. Acta Horticulturae, v.1087, p.105-111, 2015. DOI: <10.17660/ ActaHortic.2015.1087.11>

SONG, A.; AN, J.; GUAN, Z.; JIANG, J.; CHEN, F.; LOU, W.; FANG, W.; LIU, Z.; CHEN, S. The constitutive expression of a two transgene construct enhances the abiotic stress tolerance of chrysanthemum. Plant Physiology and Biochemistry, v.80, p.114-120, 2014a. DOI: $<10.1016 /$ j. plaphy.2014.03.030>

SONG, A.; ZHU, X.; CHEN, F.; GAO, H.; JIANG, J.; CHEN, S. A Chrysanthemum heat shock protein confers tolerance to abiotic stress. International Journal of Molecular Sciences, v.15, n.3, p.5063-5078, 2014b. DOI: $<10.3390 /$ ijms 15035063>

SUBBURAJ, S.; CHUNG, S.J.; LEE, C.; RYU, S.M.; KIM, D.H., KIM, J.S.; BAE, S.; LEE, G.J. Site-directed mutagenesis in Petunia $\times$ hybrida protoplast system using direct delivery of purified recombinant Cas9 ribonucleoproteins. Plant Cell Reports, v.35, n.7, p.15351544, 2016. DOI: <10.1007/s00299-016-1937-7>

SUN, D.; ZHANG, X.; LI, S.; JIANG, C.Z.; ZHANG, Y.; NIU, L. LrABCF1, a GCN-type ATP-binding cassette transporter from Lilium regale, is involved in defense responses against viral and fungal pathogens. Planta, v.244, n.6, p.1185-1199, 2016. DOI: <10.1007/s00425016-2576-5>

TANASE, K.; OTSU, S.; SATOH, S.; ONOZAKI, T. Expression levels of ethylene biosynthetic genes and senescence-related genes in carnation (Dianthus caryophyllus L.) with ultra-long-life flowers. Scientia Horticulturae, v.183, p.31-38, 2015. DOI: $<10.1016 / j$. scienta.2014.11.025>
VAN DER SALM, T.P.M.; VAN DER TOORN, C.J.G.; BOUWER, R.; HÄNISCH TEN CATE, C.H.; DONS, H.J. Production of ROL gene transformed plants of Rosa hybrida L. and characterization of their rooting ability. Molecular Breeding, v.3, n.1, p.39-47, 1997. DOI: $<10.1023 /$ A:1009617704014>

VANDENBUSSCHE, M.; CHAMBRIER, P.; RODRIGUES BENTO, S.; MOREL, P. Petunia, your next supermodel?. Frontiers in Plant Science, v.7, p.72 2016. DOI: $<10.3389 /$ fpls.2016.00072>

WAN, X.L.; ZHOU, Q.; WANG, Y.Y.; WANG, W.E.; BAO, M.Z.; ZHANG, J.W. Identification of heat-responsive genes in carnation (Dianthus caryophyllus L.) by RNAseq. Frontiers in Plant Science, v.6, p.519, 2015. DOI: $<10.3389 /$ fpls.2015.00519>

WANG, H.; LIU, G.; LI, C.; POWELL, A.L.T.; REID, M.S.; ZHANG, Z.; JIANG, C.Z. Defence responses regulated by jasmonate and delayed senescence caused by ethylene receptor mutation contribute to the tolerance of petunia to Botrytis cinerea. Molecular Plant Pathology, v.14, n.5, p.453-469, 2013a. DOI: <10.1111/mpp.12017>

WANG, H.; STIER, G.; LIN, J.; LIU, G.; ZHANG, Z.; CHANG, Y.; REID, M.S.; JIANG, C.Z. Transcriptome changes associated with delayed flower senescence on transgenic petunia by inducing expression of etr 1-1, a mutant ethylene receptor. PLOS one, v.8, n.7, p.e65800, 2013b. DOI: <10.1371/journal.pone.0065800>

WANG, K.; ZHONG, M.; WU, Y.H.; BAI, Z.Y.; LIANG, Q.Y.; LIU, Q.L.; PAN, Y.Z.; ZHANG, L.; JIANG, B.B.; JIA, Y.; LIU, G.L. Overexpression of a chrysanthemum transcription factor gene $D g N A C 1$ improves the salinity tolerance in chrysanthemum. Plant Cell Reports, v.36, n.4, p.571-581, 2017. DOI: <10.1007/s00299-017-2103-6>

WU, L.; MA, N.; JIA, Y.; ZHANG, Y.; FENG, M.; JIANG, C.Z.; MA, C.; GAO, J. An ethylene-induced regulatory module delays flower senescence by regulating cytokinin content. Plant Physiology, v.173, n.1, p. 853-862, 2017. DOI: <10.1104/pp.16.01064>

YAGI, M.; KOSUGI, S.; HIRAKAWA, H.; OHMIYA, A.; TANASE, K.; HARADA, T.; KISHIMOTO, K.; NAKAYAMA, N.; ICHIMURA, K.; ONOZAKI, T.; YAMAGUCHI, H.; SASAKI, N.; MIYAHARA, T.; NISHIZAKI, Y.; OZEKI, Y.; NAKAMURA, N.; SUZUKI, T.; TANAKA, Y.; SATO, S.; SHIRASAWA, K.; ISOBE, S.; MIYAMURA, Y.; WATANABE, A.; NAKAYAMA, S.; KISHIDA, Y.; KOHARA, M.; TABATA, S. Sequence analysis of the genome of carnation (Dianthus caryophyllus L.). DNA Research, v.21, n.3, p.231-241, 2014. DOI: $<10.1093 /$ dnares/dst053> 
YIN, J.; CHANG, X.; KASUGA, T.; BUI, M.; REID, M.S.; JIANG, C.Z. A basic helix-loop-helix transcription factor, PhFBH4, regulates flower senescence by modulating ethylene biosynthesis pathway in petunia. Horticulture Research, v.2, p.15059, 2015. DOI: <10.1038/ hortres.2015.59>

YUE, Y.; YIN, C.; GUO, R.; PENG, H.; YANG, Z.; LIU, G.; $\mathrm{BAO}, \mathrm{M}$; HU, H. An anther-specific gene PhGRP is regulated by PhMYC2 and causes male sterility when overexpressed in petunia anthers. Plant Cell Reports, v.36, n.9, p.1401-1415, 2017. DOI: <10.1007/s00299-017-2163-7>

ZAKIZADEH, H.; LÜTKEN, H.; SRISKANDARAJAH, S.; SEREK, M.; MÜLLER, R. Transformation of miniature potted rose (Rosa hybrida cv. Linda) with $\mathrm{P}_{S A G 12}-i p t$ gene delays leaf senescence and enhances resistance to exogenous ethylene. Plant Cell Reports, v.32, n.2, p.195-
205, 2013. DOI: <10.1007/s00299-012-1354-5>

ZHANG, B.; YANG, X.; YANG, C.; LI, M.; GUO, Y. Exploiting the CRISPR/Cas9 system for targeted genome mutagenesis in petunia. Scientific Reports, v.6, p.20315, 2016. DOI: $<10.1038 /$ srep20315>

ZVI, M.M.B.; SHKLARMAN, E.; MASCI, T.; KALEV, H.; DEBENER, T.; SHAFIR, S.; OVADIS, M.; VAINSTEIN, A. PAP1 transcription factor enhances production of phenylpropanoid and terpenoid scent compounds in rose flowers. New Phytologist, v.195, n.2, p.335-345, 2012. DOI: $<10.1111 /$ j.1469-8137.2012.04161.x $>$ 